\title{
PENGARUH PERSEPSI TENTANG PENGETAHUAN, PERATURAN, DAN MANFAAT PERPAJAKAN TERHADAP KEPATUHAN WAJIB PAJAK UMKM PADA KPP PRATAMA SURAKARTA
}

\author{
Sari Wiyati, Endang Masitoh, Anita Wijayanti \\ Universitas Islam Batik Surakarta, Jl. Agus Salim No. 10 \\ sari.saririe@gmail.com
}

\begin{abstract}
This study aims to determine whether there is a partial influence on knowledge of taxation, tax regulations and tax benefits. The sampling technique in this study used simple rondom sampling, then obtained a study sample of 100 MSME tax payers. Data analysis techniques performed by descriptive statistical tests, classical assumptions, hypothesis testing with linear regression analysis. The results showed that knowledge of taxation and tax regulations had a positive effect on MSME taxpayer compliance in KPP Pratama Surakarta while the tax benefits did not affect MSME taxpayer compliance in KPP Pratama Surakarta.
\end{abstract}

Keywords: Tax compliance, tax knowledge, tax benefits and tax complianc

\section{PENDAHULUAN}

Kinerja pajak di Indonesia yang belum maksimal, tercermin melalui masih eendahnya tax ratio serta masih terjadinya tax gap di Indonesia. Kebijakan Pemerintah dengan pemberlakuan Self assessment system, dengan tujuan agar Wajib Pajak dapat berperanserta dalam pembayaran pajak secara dan keseluruhan sesuai dengan peraturan pajak sendiri, sehingga dengan kewenangan yang diberikan pihak-pihak tersebut mampu mengerti dan melaksanakan peraturan pajak. Akan tetapi system tersebut masih belum berperan dalam peningkatan penerimaan pajak, karena jumlah wajib pajak dan meningkatkan pendapatan pajak masih rendahnya kesadaran masyarakat dalam pembayaran pajak serta minimnya pengetahuan masyarakat akan manfaat perpajakan bagi masyarakat dan Negara.

Sumber utama penerimaan suatu negara adalah dari pajak, karena dengan pajak sebagian besar kegiatan negara akan mudah terlaksana. Mengingat sangat pentingnya pendapatan negara melalui pajak maka Pemerintah mengeluarkan suatu kebijakan yang strategis maupun yang sifatnya pendukung dengan menerapkan peraturan - peraturan tertentu untuk meningkatkan pendapatan pajak yakni melalui Peraturan Pemerintah dan Peraturan Menteri Keuangan. 


\section{TINJAUAN PUSTAKA}

\subsection{Tinjauan Pustaka}

\section{Pengertian Pajak}

Pajak ialah iuran warga negara yang bersifat memaksa, yang disetorkan kepada negara yang terutang oleh WPOP atau badan sesuai ketentuan perundang-Undangan, yang penerimaan imbalannya secara tidak langsung yang penggunaannya untuk kepentingan negara serta untuk kemakmuran rakyat." (UU No.28 tahun 2007 pasal 1).

\section{Usaha Mikro Kecil dan Menengah}

\section{Tabel 1}

Kriteria UMKM

\begin{tabular}{llll}
\hline No. & \multicolumn{1}{c}{ URAIAN } & \multicolumn{2}{c}{ KRITERIA } \\
\cline { 3 - 4 } & \multicolumn{1}{c}{ Asset } & \multicolumn{1}{c}{ Omzet } \\
\hline 1. & Usaha Mikro & Maks. 50 Juta & Maks. 300 Juta \\
2. & Usaha Kecil & $>50$ Juta -500 Juta & $>$ 300 Juta $-2,5$ Miliar \\
3. & Usaha Menengah & $>500$ Juta -10 Miliar & $>2,5$ Miliar -50 Miliar
\end{tabular}

Sumber: www.depkop.go.id

\section{Pengetahuan Pajak}

Pengetahuan merupakan suatu informasi yang sudah dikombinasikan dengan pemahaman serta potensi untuk bertindak.

\section{Peraturan Pajak}

Tahun 1945 urusan bea/pajak dipegang oleh Departemen Keuangan bagian Pajak, dan di tahun 1950 lembaga tersebut berubah nama menjadi Djawat 21 Pajak yang dibagi dua, antara lain pajak pusat dan pajak daerah dan berlaku di seluruh Indonesia.

\section{Manfaat Pajak}

Negara menjadi dominan merupakan salah satu manfaat dalam mendukung kegiatan pemerintahan. Pajak yang dibayarkan oleh masyarakat akan dipergunakan oleh negara guna mensejahterakan rakyat, diantaranya memberi subsidi yang dibutuhkan masyarakat dan untuk mengangsur serta melunasi hutang - hutang negara

\subsection{Kerangka Pemikiran}

Hipotesis dalam penelitian ini mengenai pengetahuan, peraturan dan manfaat perjkan terhadap kepatuhan WP 


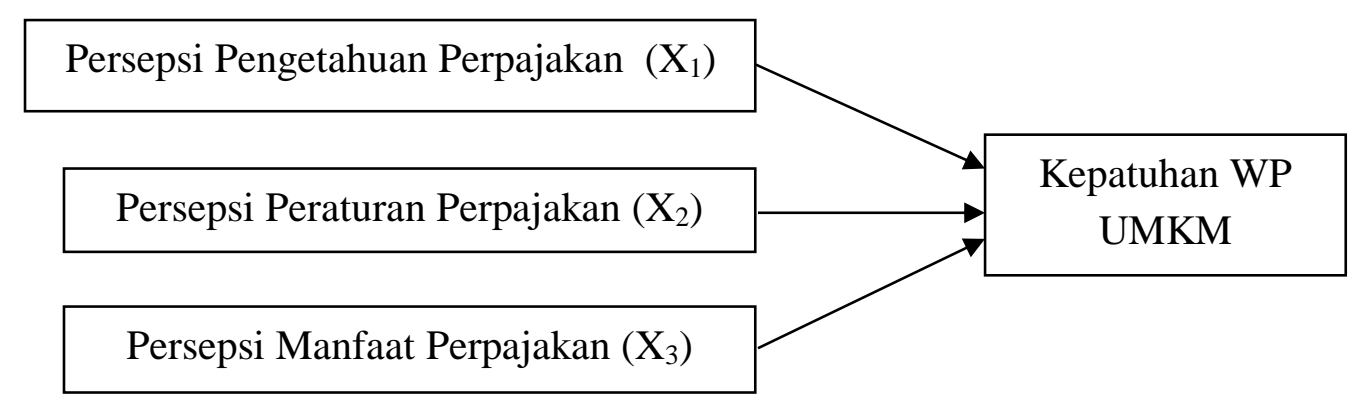

\section{METODE PENELITIAN}

Penelitian ini menggunakan pendekatan kuantitaf. menggunakan teknik pengumpulan dan analisis data untuk mendapatkan informasi yang harus disimpulkan. Dalam penelitian ini populasinya adalah wajib pajak UMKM yang memiliki pengahasilan atau pendapatan kotor kurang dari 4,8 miliar pada satu tahun masa pajak di KPP Pratama kota Surakarta. Besar populasi berdasar data yang penulis peroleh sebanyak 10.878 wajib pajak adapun jumlah sampel yang digunakan oleh penulis berdasar rumus Slovin sebanyak 100 responden.

\section{HASIL DAN PEMBAHASAN}

\subsection{Asumsi Klasik}

1) Uji Normalitas

Tabel 2

Hasil Uji Normalitas

\begin{tabular}{lccc}
\hline \multicolumn{1}{c}{ Variabel } & Sig. & $\begin{array}{c}\text { Standard } \\
\text { Sig. }\end{array}$ & Keterangan \\
\hline Kepatuhan Wajib pajak & 0,179 & 0,05 & Normal \\
Pengetahuan Perpajakan & 0,122 & 0,05 & Normal \\
Peraturan Perpajakan & 0,200 & 0,05 & Normal \\
Manfaat Perpajakan & 0,46 & 0,05 & Normal \\
\hline
\end{tabular}

Dari tabel tersebut diketahui nilai sig > 0,05 makan dapat dismpulkan data berdistribusi normal. 
2) Uji Multikolinearitas

\section{Tabel 3}

Hasil Uji Multikolinearitas

\begin{tabular}{cccccc}
\hline Variabel & Tolerance & $\begin{array}{c}\text { Std. } \\
\text { Tolerane }\end{array}$ & VIF & Std. VIF & Keterangan \\
\hline $\mathrm{X}^{1}$ & 0,135 & $>0,1$ & 7,388 & $<10$ & $\begin{array}{c}\text { Tidak terjadi } \\
\text { Multikolinearitas } \\
\text { Tidak terjadi } \\
\mathrm{X}^{2}\end{array}$ \\
& 0,114 & $>0,1$ & 8,803 & $<10$ & $\begin{array}{c}\text { Multikolinearitas } \\
\text { Tidak terjadi } \\
\mathrm{X}^{3}\end{array}$ \\
& 0,146 & $>0,1$ & 8,843 & $<10$ & Multikolinearitas \\
\hline
\end{tabular}

Berdasarkan tabel diatas dismpulkan bahwaketiga variable independen tidak terjadi Multikolinearitas.

\section{3) Uji Hesteroskidastisitas}

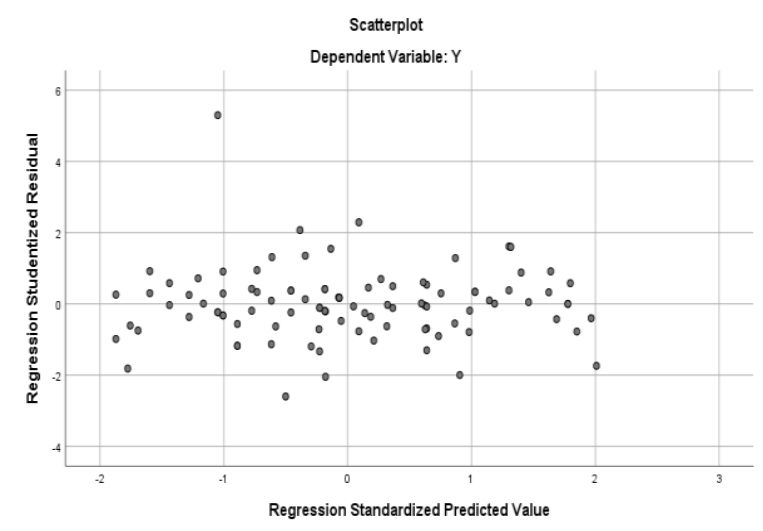

Berdasar Gambar disamping dapat dilihat bahwa titik-titik tersebar tidak teratur atau secara acak, sehinggadapat disimpulkan bahwa tidak terjadi gejala heteroskedasitas.

4) Uji Autokorelasi

Tabel 4

Hasil Uji Autokorelasi

\begin{tabular}{ccccc}
\hline DW & DU & 4-DU & Standart & Keterangan \\
\hline 2,097 & 1,735 & 2,265 & DU $<$ DW $<4-\mathrm{DU}$ & $\begin{array}{c}\text { Tidak terdapat } \\
\text { autokorelasi }\end{array}$ \\
\hline
\end{tabular}

Menurut tabel IV.13 diatas dapat dilihat bahwa nilai DW sebesar 1,888. Untuk nilai DU dapat dilihat pada Durbin-Watson tabel pada signifikansi 5\% atau 0,05, sampel 100 $(\mathrm{n}=100)$ serta variabel independen $3(\mathrm{k}=3)$, maka di tabel Durbin Watson akan diperoleh nilai DU sebesar 1,735. Jadi nilai 4-DU $=4-1,735=2,265$. Maka nilai DW 
terdapat antara DU < DW < 4-DU atau 1,735 < 2,097 < 2,265. Hasil ini menyatakan bahwa regresi bebas masalah autokorelasi

\subsection{Pengujian Hipotesis}

1) Model Regresi

Hasil persamaan linier berganda berikut:

$$
Y=2,197+0,394 X^{1}+0,377 X^{2}+0,162 X^{3}+\varepsilon
$$

2) Uji Ketetapan Model (Uji F)

\section{Tabel 5}

Hasil Uji F

\begin{tabular}{cccccc}
\hline Model & $\mathbf{F}_{\text {hitung }}$ & $\mathbf{F}_{\text {tabel }}$ & Sig. & Standar Sig. & keterangan \\
\hline Regression & 140,959 & 2,70 & 0,000 & $<0,05$ & Ha diterima \\
\hline
\end{tabular}

Berdasarkan tabel diatas dapat disimpulkan bahwa Pengetahuan pajak, Peraturan pajak dan Manfaat pajak berpengaruh signifikansi secara simultan kepada kepatuhan WP UMKM dalam pelaporan SPT Tahunan pada KPP Pratama Surakarta.

\section{3) Uji Hipotesis}

\section{Tabel 6}

Hasil Uji t

\begin{tabular}{lccccc}
\hline \multicolumn{1}{c}{ Variabel } & $\mathbf{t}_{\text {hitung }}$ & $\mathbf{t}_{\text {tabel }}$ & Sig. & $\begin{array}{c}\text { Standar } \\
\text { Sig. }\end{array}$ & Keterangan \\
\hline Pengetahuan & & & & & \\
Perpajakan & 3,131 & 1,985 & 0,002 & $<0,05$ & Diterima \\
Peraturan Perpajakan & 3,012 & 1,985 & 0,003 & $<0,05$ & Diterima \\
Manfaat Perpajakan & 1,417 & 1,985 & 0,160 & $<0,05$ & Ditolak \\
& & & & & \\
\hline
\end{tabular}

\section{a) Pengujian Hipotesis 1 (Pengetahuan Perpajakan)}

Hasil Uji t di sajikan pada tabel 6 bahwa $t_{\text {hitung }}=3,131$ dan signifikansi $=0,002$. Karena nilai $t_{\text {hitung }}>t_{\text {tabel }}(3,131>1,985)$, dan nilai signifikansi $<0,05(0,002<0,05)$, maka bisa disimpulkan H1 diterima, artinya pengetahuan perpajakan bepengaruh terhadap kepatuhan wajib pajak UMKM dalam pelaporan SPT Tahunan pada KPP Pratama Surakarta.

\section{b) Pengujian Hipotesis 2 (Peraturan Perpajakan)}

Hasil Uji t di sajikan pada tabel 6 bahwa $t_{\text {hitung }}$ sebesar 3,0122 dengan signifikansi sebesar 0,003. Karena nilai $t_{\text {hitung }}$ lebih besar $t_{\text {tabel }}(3,012>1,985)$, serta nilai signifikansi $<0,05(0,003<0,05)$, maka kesimpulannya $\mathrm{H} 2$ diterima, artinya peraturan 
perpajakan bepengaruh terhadap kepatuhan wajib pajak UMKM dalam pelaporan SPT Tahunan pada KPP Pratama Surakarta.

\section{c) Pengujian Hipotesis 3 (Manfaat Perpajakan)}

Hasil Uji t yang telah di sajikan pada tabel 6 dilihat bahwa thitung sebesar 1,417 dengan signifikansi sebesar 0,160 . Karena nilai $\mathrm{t}$ hitung $<\mathrm{t}$ tabel $(1,417<1,985)$, dan nilai signifikansi > 0,05 $(0,160<0,05)$, maka dapat disimpulkan bahwa H2 ditolak, artinya manfaat perpajakan tidak bepengaruh terhadap kepatuhan wajib pajak UMKM dalam pelaporan SPT Tahunan pada KPP Pratama Surakarta.

\section{KESIMPULAN}

Hasil hipotesis 1 pada penelitian ini adalah diterima, artinya pengetahuan perpajakan mempunyai pengaruh terhadap kepatuhan WP UMKM. Hasil penelitian ini sesuai penelitian (Rahayu, 2017) dan (Kusumasari \& Suardana, 2018). Kemudian hipotesis 2 diterima, yang artinya peraturan perpajakan mempunyai pengaruh terhadap kepatuhan WP UMKM. Penelitian ini sesuai penelitian (Adiasa, 2013) dan (Mustofa, Kertahadi, \& R, 2016). Kemudian untuk hipotesis 3 ditolak yaitu manfaat perpajakan tidak berpengaruh terhadap kepatuhan WP UMKM. Penelitian ini sesuai dengan (Masruroh \& Zulaikha, 2013).

\section{DAFTAR PUSTAKA}

Adiasa, N. (2013). Accounting Analysis Journal. Pengaruh Pemahaman Peraturan Pajak Terhadap Kepatuhan Wajib Pajak Dengan Moderating Preferensi Risiko, Vol. 2(No. 3), 345-352.

Ariyanti, F. (Ed.). (2018, Agustus 21). Memahami Pajak Umkm, Keuntungan, Dan Cara Perhitungannya. Retrieved Februari 20, 2019, From Https://Www.Cermati.Com.

Ghozali, I. (2011). Aplikasi Analisis Multivariate Dengan Program Ibm Spss 20. Surakarta: Uniba Perss.

Hardiningsih, Pancawati, \& Yulianawati, N. (2011). Jurnal Dinamika Keuangan Dan Perbankan. Faktor-Faktor Yang Mempengaruhi Kemauan Membayar Pajak, Vol. 3(No. $1)$.

Huda, A. (2015). Pengaruh Persepsi Atas Efektifitas Sistem Perpajakan, Kepercayaan, Tarif Pajak Dan Kemanfaatan Npwp Terhadap Kepatuhan Membayar Pajak. Jom Fekon, Vol. 2(No.2), 1-15.

Ilhamsyah, R., Endang, M. G., \& Dewantara, R. Y. (2016). Jurnal Perpajakan (Jejak). Pengaruh Pemahaman Dan Pengetahuan Wajib Pajak Tentang Peraturan Perpajakan, Kesadaran Wajib Pajak, Kualitas Pelayanan, Dan Sanksi Perpajakan Terhadap Kepatuhan Wajib Pajak Kendaraan Bermotor (Studisamsat Kota Malang), Vol. 8(No. 1).

Kamil, N. I. (2015). Jurnal Penelitian Keuangan Akuntansi. Pengaruh Kesadaran Wajib Pajak, Pengetahuan, Denda Pajak Dan Layanan Otoritas Pajak Tentang Kepatuhan Pajak, Vol. 6(No. 2), 2222-1697. 
Kiryanto. (2000). Ekobis. Analisis Pengaruh Penerapan Struktur Pengendalian Intern Terhadap Kepatuhan Wajib Pajak Bada Dalam Memenuhi Kewajiban Pajak Penghasilan, Vol. 1(No. 1), 41-51.

Kusumasari, N. K., \& Suardana, K. A. (2018). E-Jurnal Akuntansi Universitas Udayana. Pengaruh Pengetahuan Perpajakan, Kesadaran Dan Pengetahuan Tax Amnesty Pada Kepatuhan Wpop Di Kpp Pratama Gianyar, Vol.22(No. 2), 1503-1529.

Mardiasmo. (2009). Perpajakan Edisi Revisi. Yogyakarta: Andi Offiset.

Masruroh, S., \& Zulaikha. (2013). Pengaruh Kemanfaaatan Npwp, Pemahaman Wajib. Diponegoro Journal Of Accounting, Vol. 2(1-15).

Mustofa, F. A., Kertahadi, \& R, M. M. (2016). Pengaruh Pemahaman Peraturan Perpajakan, Tarif Pajak. Jurnal Perpajakan (Jejak), Vol.8(No. 1), 1-7.

Rahayu, N. (2017). Akuntansi Dewantara. Pengaruh Pengetahuan Perpajakan, Ketegasan Sanksi Pajak, Dan Tax Amnesty Terhadap Kepatuhan Wajib Pajak, Vol. 1(No. 1), 15-29.

Rahayu, S. K. (2010). Perpajakan Indonesia. Yogyakarta: Graha Ilmu.

Resmi, S. (2003). Perpajakan Teori Dan Kasus. Yogyakarta: Salemba Empat.

Sari, R. (2018). Pusat Penelitian Badan Keahlian Dpr Ri. Kebijakan Insentif Pajak Bagi Usaha Mikro, Kecil, Dan Menengah, Vol. X(No. 12), 19-24.

Simanjuntak, \& Mukhlis. (2012). Pengaruh Modernisasi Sistem Administrasi Dan Sanksi Perpajakan Pada Kepatuhan Wajib Pajak. In Dimensi Ekonomi Perpajakan Dalam Pembangunan Ekonomi. Jakarta: Raih Asa Sukses.

Soemarso. (2010). Asas Dan Dasar Perpajakan I. Bandung: Pt. Refika Aditama. Sugiyono. (2009). Metodologi Penelitian Bisnis. Bandung: Cv Alfabeta.

Suryadi. (2006). Jurnal Keuangan Publik. Model Hubungan Kausal Kesadaran, Pelayanan, Kepatuhan Wajib Pajak Dan Pengaruhnya Terhadap Kinerja Penerimaan Pajak, Vol. 4(No. 1), 105-121.

Utami, Rizki, S., Andi, \& Soerono, A. N. (2012). Pengaruh Faktor-Faktor Ekternal Terhadap Tingkat Kepatuhan Wajib Pajak Di Lingkungan Kantor Pelayanan Pajak Pratama Serang. P. Makalah Simposium Nasional Akuntansi XV. Banjarmasin. 